\title{
Basement-involved tectonics in North Fossa Magna, central Japan: The significance of the northern Itoigawa-Shizuoka Tectonic Line
}

\author{
Akira Takeuchi \\ Deptartment Earth Science, Toyama University, Japan \\ (Received June 16, 2004; Revised October 31, 2004; Accepted December 13, 2004)
}

\begin{abstract}
The Toyama Trough and Fossa Magna basin are major transverse tectonic depressions located between northeast Japan (NEJ) and southwest Japan (SWJ). Itoigawa-Shizuoka Tectonic Line (ISTL), the western margin of Fossa Magna is a boundary between two tectonic provinces along the inner side of NEJ and SWJ. Abrupt lateral variations in thickness of the Middle to Upper Miocene strata are quite significant among these provinces in the North Fossa Magna. The development of the thrust/fold belt is attributed not only to horizontal compression but also to vertical block movements as basement-involved tectonics. In response to the Pliocene and later compression regime, the old fault-block boundaries were reactivated and produced differential block movement such as the tilting of the Central Upheaval Zone and uplifting of the Nishikubiki Belt. One possible model for the deeper geologic structure is presented that high-angled block faults on the surface among tectonic provinces originate in vertical weak zones in the deep seismogenic zone under the sedimentary layer. The folded Neogene system comprises the present-day thrust-fault province of the North Fossa Magna and the stress regime of strikeslip faulting occupies the basement, as inferred from focal mechanism solutions for small events. In order to account for the apparent discrepancy, a duplex stress field is possible for the active tectonics in the region.
\end{abstract}

Key words: Seismotectonics, neotectonics, seismogenic zone, island arc, active fault, weak zone.

\section{Introduction}

The Fossa Magna region, a major transverse zone of Miocene tectonic depression, cutting the central highland of Honshu Island is a triple juncture of the northeast Japan (NEJ) arc and Izu-Bonin arc belonging to the Eastern island arc system, and the southwest Japan (SWJ) arc to the western Japan Arc systems (Sugimura and Uyeda, 1973; see Fig. 1). Northwardly, the depression extends in the Toyama Trough and southwardly connects to both the Sagami and the Suruga Troughs on the Pacific side. The west margin of the Fossa Magna, the Itoigawa-Shizuoka Tectonic Line (ISTL), defined as the western margin of the Miocene sedimentary basin developed at the southwest termination of intra-arc basin along the inner belt of the northeast Honshu arc, although there is no clear definition about the eastern margin. It divides tectonic provinces between NEJ and SWJ.

If we look at a small-scaled topographic map of the Japanese islands (Figs. 1, 2), there is no doubt that the arc boundary can be extended northward into the Japan Sea and runs down through the Toyama Trough onto the eastern margin of the Yamato Basin, and that the Toyama Trough terminates both the Sado Ridge (Fig. 2) and the coastal shelf of the NEJ side, which are characterized by ragged topography due to the Pliocene and later crustal deformation along the eastern margin of the Japan Sea. Contrastingly, the geomorphology of the coastal shelf of the SWJ side is compar-

Copy right(c) The Society of Geomagnetism and Earth, Planetary and Space Sciences (SGEPSS); The Seismological Society of Japan; The Volcanological Society of Japan; The Geodetic Society of Japan; The Japanese Society for Planetary Sciences; TERRAPUB atively smooth and the Toyama trough bounds both sides.

In the 19th and 20th centuries, a line of six strong earthquakes larger than magnitude 7.0 on the Richter scale were generated in the tectonic zone along the eastern margin of the Japan Sea and the North Fossa Magna region (Fig. 1; e.g. Takeuchi et al., 1998). The southern part of the earthquake sequence, including the 1964 Niigata (M7.5) and 1847 Zenkoji (M7.4) events, is known as the Shinanogawa seismic zone (Nakamura and Matsuda, 1968). The fact that strong earthquakes occur along the selected block boundaries, ISTL, and Shinanogawa zone denotes the closest relationship between the tectonic history and present-day seismogenic subject. Hypocenters are considered to be more than $15 \mathrm{~km}$, which is significantly deeper than the basal horizon of the sedimentary cover. This paper refers to longterm block movement and its reactivation as evidence for the presence of a weak zone at a seismogenic depth. In order to characterize the seismogenic faults in the North Fossa Magna region and the northern ISTL, the paper analyzes and discusses the geohistory and neotectonics, and then presents an evolutionary model for the location of strong earthquakes.

Since the Neogene ISTL had already been buried and modified by later sedimentation and deformation, it is not easy to restore its original position. One can trace ISTL by means of recently active faults. In the northernmost portion of ISTL, a few outcrops were known and each fault contact of the Neogene strata with the older bedrocks is almost vertical. Another aspect to recognize the northern ISTL is the idea of the Omine Belt (Kosaka, 1991), which is not a fault line but a narrow tectonic zone of the Pleistocene 


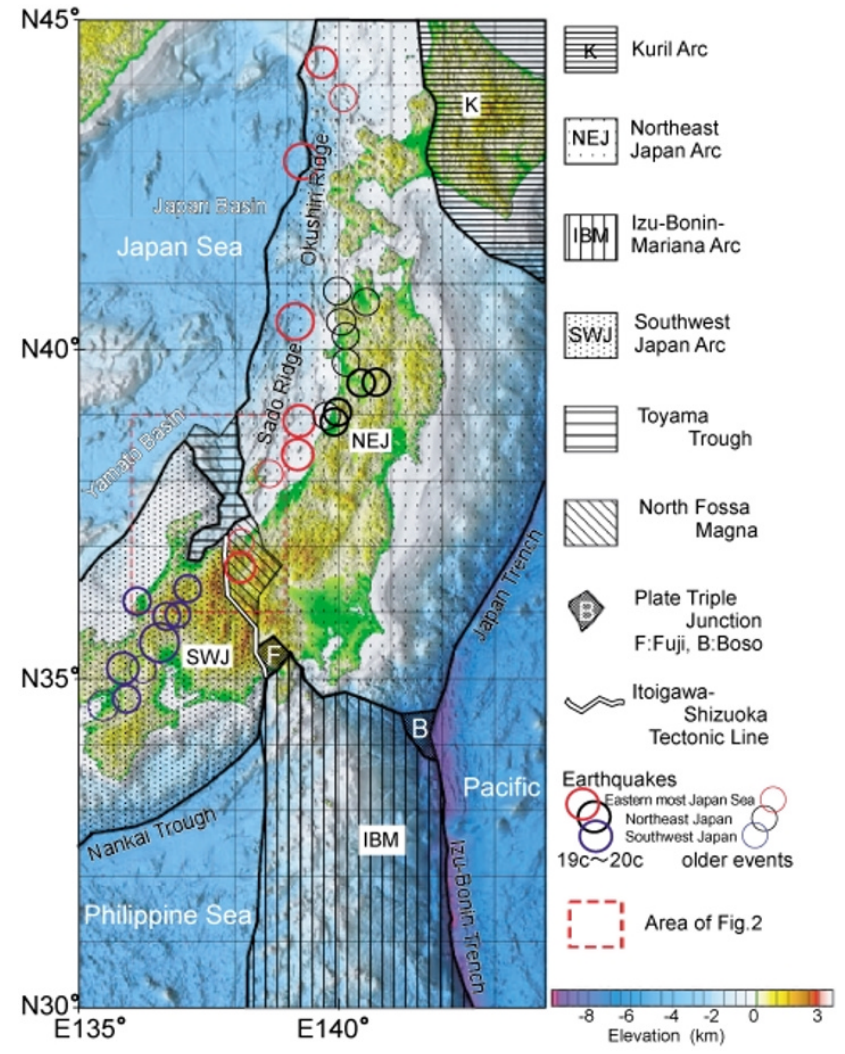

Fig. 1. Tectonic situation of central Japan. The northeast Japan (NEJ), southwest Japan (SWJ) and Izu-Bonin-Mariana (IBM) arcs converge in central Japan to form two sites of triple junction. Fuji junction (F) concerns the convergence among SWJ on Amuria Plate, NEJ on Okhotsk Plate and IBM on Philippine Sea Plate, while Boso junction (B) relates with NEJ, IBM and Pacific Plate. The Itoigawa-Shizuoka Tectonic Line (ISTL) on land as well as the Toyama Trough bounds SWJ and NEJ arcs. Epicenters for historical earthquakes are also shown. Thick open circles: 19-20 centuries, thin circles: older than 18 century. Red colored events occurred in the eastern margin of Japan Sea, black in the inland area of NEJ and Blue in the inland of SWJ.

sedimentary basin along the western margin of the North Fossa Magna region.

\section{Method and Data}

Mapping of the surface geology of the North Fossa Magna had already been done by the 1990s, and all fundamental data for discussing the deeper geologic structure and its relationship with the seismic activity in the basement have been prepared. Nowadays, it is easy to examine the geological features of a widespread area since the Geological Survey of Japan compiled existing data and published geologic maps on the reduced scale of 1:50,000 and the 1:200,000 maps on active tectonics became available on CD-ROM (GSJ, 2002b, 2003). Lately, after the 1995 Kobe earthquake disaster, in order to evaluate the feasibility of retrieving a suitable location for nuclear waste processing in Japan, all previous studies on the geology, geophysics, and geochemistry including the distribution of active faults, volcanoes, marine terraces, and ancient coastal lines, were compiled into electric media (Takeuchi, 1999; Nakata and Imaizumi, 2000; Koike and Machida, 2001). A similar circumstance has been established to study marine geology off the North Fossa Magna, including data

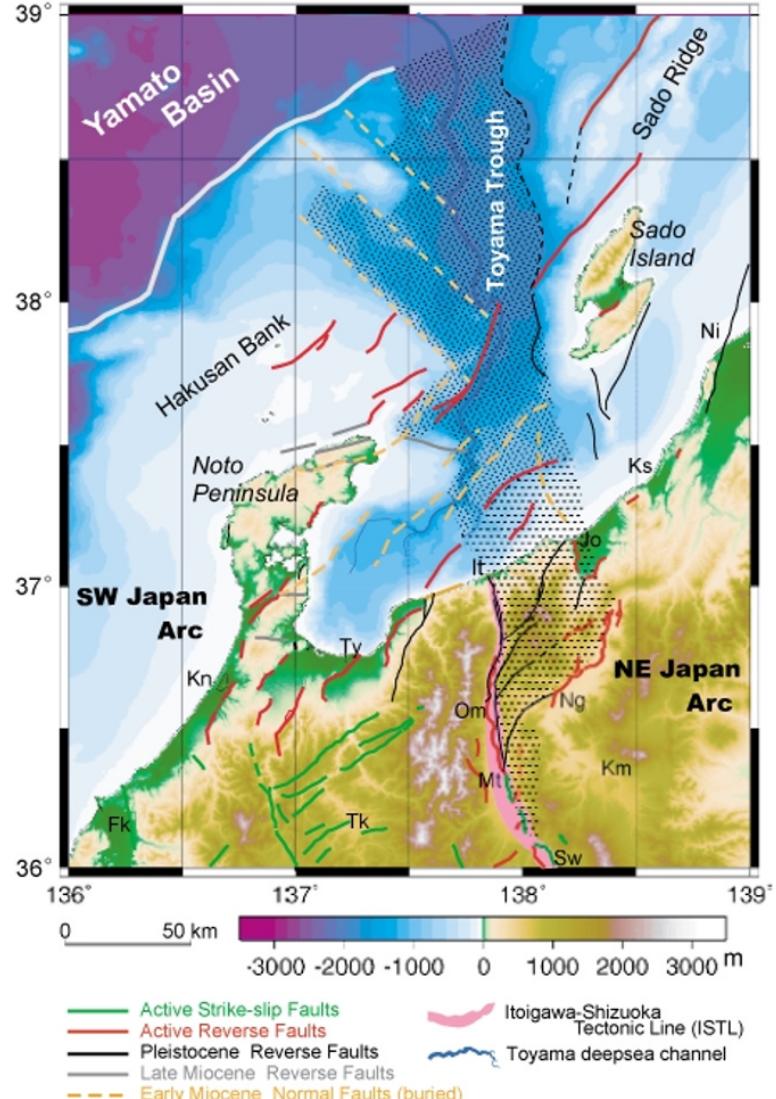

Fig. 2. Index map of inner (Japan Sea) side of central Japan. Both the Present Toyama Trough (dotted) and the Neogene sedimentary basin (horizontally striped by thin broken lines) split the continental slope of Honshu Island. While surface thrust and fold belts in NE-SW trends develop throughout the map area, it is recognizable that most faults in NW-SE and NNW-SSE trends tend to concentrate within a zone of North Fossa Magna and Toyama Trough. Abbreviation for locality names: Niigata (Ni), Kashiwazaki (Ks), Joetsu (Jo), Itoigawa (It), Nagano (Ng), Omachi (Om), Matsumoto (Mt), Komoro (Km), Suwa (Sw), Toyama (Ty), Takayama (Tk), Kanazawa (Kn), Fukui (Fk)

of the distribution pattern of submarine active faults (GSJ, 2002a; Okamura, 2003). Utilizing all these data, a comparative method should be attempted according to the abovementioned structural continuance of geomorphology and stratigraphy. For example, the deeper geologic structure of North Fossa Magna might be analogous with that of the Toyama Trough, since the deformation of sedimentary layers in the latter is less severe than in the former. Therefore the basement structure is traceable and applicable to the surrounding area based on the stratigraphic correlation of Neogene sedimentary strata.

Figure 3 illustrates an outline of geology (distribution of Miocene strata and igneous rocks) in the North Fossa Magna region based on previous studies (e.g. Takeuchi, 1981; Yamagishi and Kosaka, 1991; GSJ, 2002b, 2003; Okamura, 2003). Kono (2003) demonstrated that collapsed gravity anomalies called Conrad/Moho/Slab Residual Bouguer Anomalies (Fig. 4; with the template of zonal structure shown in Fig. 3), which correlates well with the shallow geologic structures in the North Fossa Magna (cf. Takeuchi, 1978, figure 11). This relationship can be interpreted as block faulting in the basement, resulting in thick- 


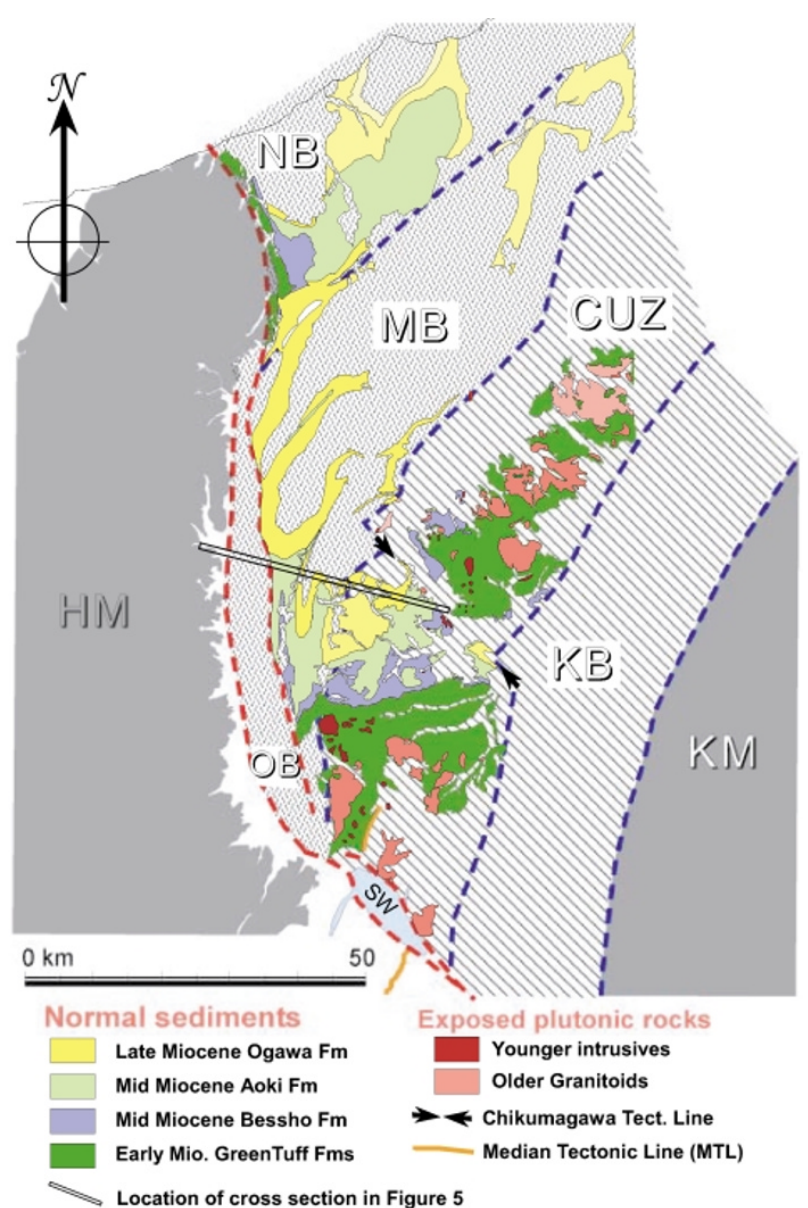

Fig. 3. Tectonic provinces of the North Fossa Magna. Distribution of Miocene stratigraphic sequence (after 1:200,000 Geologic Map; GSJ, 2003) and major tectonic zones and belts (after Kosaka, 1999) are compiled and simply reproduced. [Pre-Tertiary Basement] HM: Hida Mountains, KM: Kanto Mountains. [Tectonic province] CUZ: Central Upheaval Zone; MB: Minochi Belt, NB: Nishikubiki Belt, OB: Omine Belt; SW: Suwa depression; KB: Komoro (-Kobuchizawa) Belt. The Miocene CUZ (Obliquely striped) was wider than in the later period, from where KB was differentiated. Similarly, NB uplifted from the former sedimentary basin (dotted area) west of CUZ. Red broken lines denote the northern ISTL including OB and SW and blue lines are boundaries among tectonic belts in the North Fossa Magna.

ness variation in the sedimentary sequences of each block.

It is well known that almost all major active faults in Japan are not newly formed but reactivated pre-existing structures. The seismogenic fault for Zenkoji Earthquake is regarded as the major thrust in the Shinanogawa seismic zone between the Minochi folded belt (MB) and the Central Upheaval Zone (CUZ) of North Fossa Magna (Nakamura and Matsuda, 1968; Ikeda et al., 2002). Another important tectonic issue of the district is the seismotectonics of ISTL; what is the attitude of ISTL at a depth around 10-20 km, high angle fault or flat/lamp structure? This question also concerns how to explain mechanically the development of the thrust and fold belt in the western sedimentary basin (WSB), which comprises both the Minochi belt (MB) and the Nishikubiki upheaval belt (NB; see Fig. 3). From the geohistorical aspect, the answer must be tested in good agreement with lateral variations in thickness of the Middle to Upper Miocene strata and with the Pliocene and later

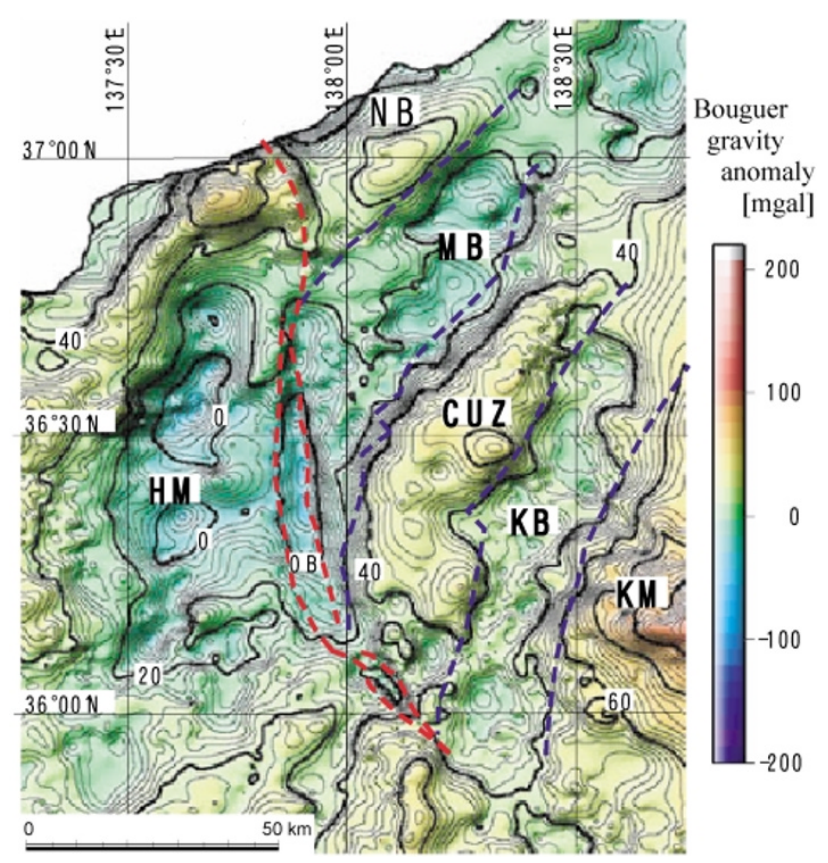

Fig. 4. Conrad, Moho, and Slab residual Bouguer anomaly map and major tectonic belts of the North Fossa Magna. In the C.M.S.R.B.A Gravity Map quoted partly from Kono (2003), where full reductions due to subducting slabs, Conrad-Moho undulations beneath the central Japan are completed. Contour interval 2 mgal. Overlain tectonic lines and zones are the same as in Fig. 3. CUZ: Central Upheaval Zone; MB: Minochi Belt, NB: Nishikubiki Belt, OB: Omine Belt; KB: Komoro Belt.

fault-block movements in CUZ, as discussed later.

Figure 5 (top) shows the geological cross section which cut the northwest-southeast trending interval from Omachi to Komoro (Om-Km in Fig. 2; also shown in Fig. 3) by utilizing the 1:50000 geologic map published by the Geogical Survey's geologic maps "Shinano Ikeda" and "Sakaki". Usually seismic reflection surveys can offer detailed information for geologic structures continuously from shallower to deeper horizons rather than other kinds of geophysical data such as seismic refraction, gravity, and electromagnetics. Unfortunately, the data acquired from the inland seismic reflection survey (e.g. Sato et al., 2004) could not evidence the deformed structure, as shown in Fig. 5, because of a lower quality than that of the off-shore seismic surveys in the Toyama Trough, conducted by petroleum exploration (e.g. Ishida, 1995) and other geological investigations (GSJ, 2002a; Okamura, 2003).

\section{Tectonic Stress Srovinces}

Figure 6 depicts active fault provinces in the inner (Japan Sea) side of central Japan (Takeuchi, 1999). Distribution of present-day active strike-slip faults are concentrated to the west of ISTL, where Cretaceous and earlier hard rocks are well exposed. Active thrust faults are distributed within the area of thick sedimentary sequences in the North Fossa Magna, Toyama Trough and Toyama Plain. Early Pleistocene reverse faults in N-S trends and Middle Miocene reverse faults in E-W trend are also distributed in the recent reverse fault province. The northwest dipping thrust faulting in the Shinanogawa zone is sided by the $10 \mathrm{~km}$ wide, 


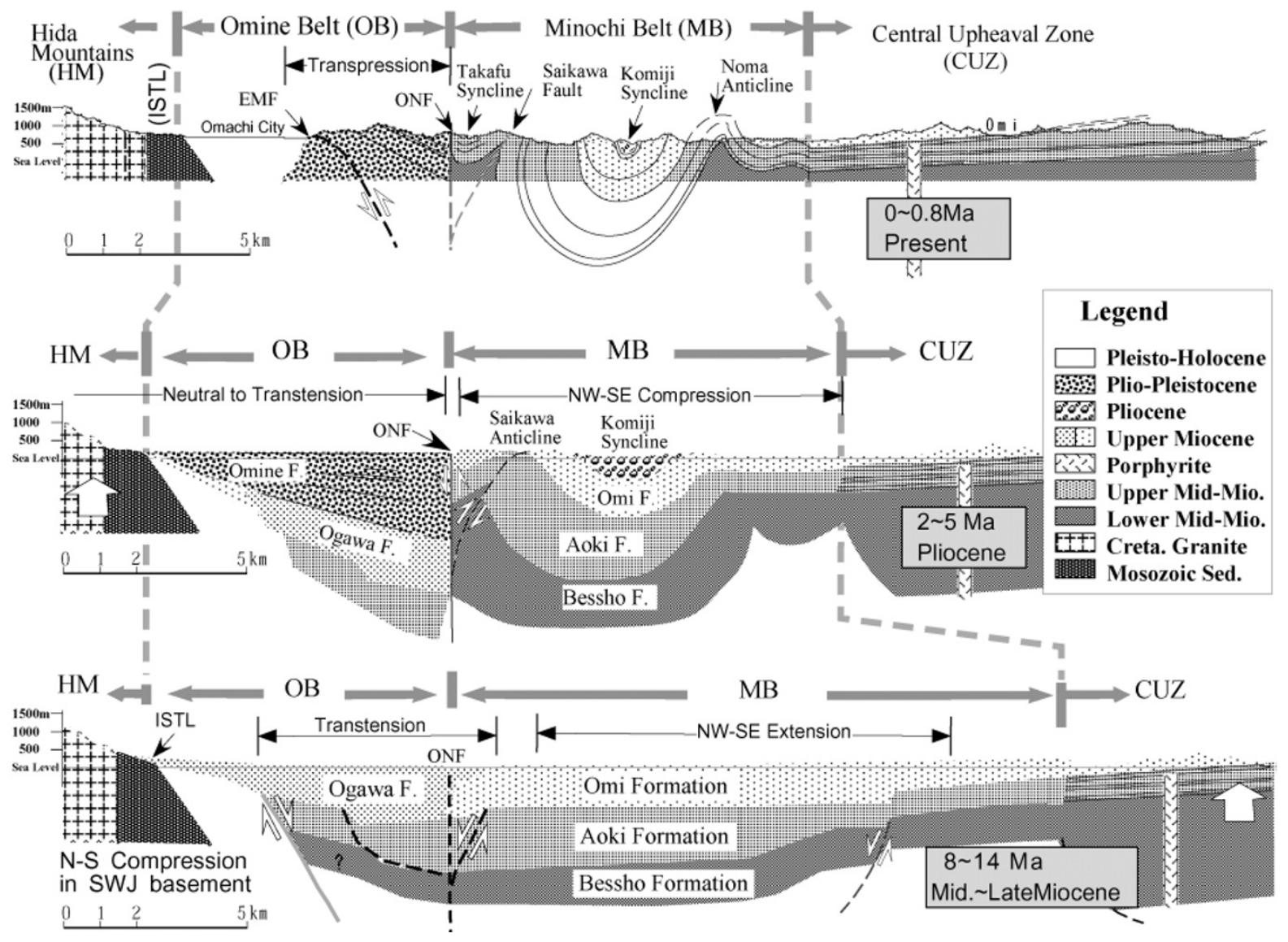

Fig. 5. Geologic cross-section of the northern Fossa Magna along the line (see Fig. 3 for location) ranging from the Omachi Belt (OB) through the Western Sedimentary Basin (WSB), into the Central Uplift Zone (CUZ). [Top] The Present geologic cross-section, compiled from 1:50,000 geologic maps (Geological Survey of Japan, 1980, 1983). The flower structure sprayed from the deeper transcurrent fault is adopted for the attitude of the northern ISTL. Restored stratigraphic sections, deduced from the present section above, are also shown for the Pliocene [Middle: 2-5 Ma] and the Late Miocene [Bottom: 8-14 Ma]. EMF: East margin fault of Matsumoto Basin, OFN: Otari-Nakayama fault.

transpressional zone of thrusting along the northern ISTL.

As for the present condition mentioned above, a duplex stress field is probable for the North Fossa Magna region, the thrust type of stress field, observable near the surface and strike-slip fault type in the basement: Inferred from the focal mechanism solutions (e.g. Ishikawa, personal comm.), strike-slip faulting is common in the basement down to some $10 \mathrm{~km}$ beneath the sedimentary sequence as well as in CUZ of the North Fossa Magna, such as the Matsushiro earthquake. The northwest dipping thrusts and related flexures are observable near the surface of the thick sedimentary cover in the Shinanogawa zone (e.g. Ikeda et al., 2002). Meanwhile, outcrops of strike-slip fault are easily observed on the surface in the SWJ side of ISTL, where sediment cover has already eroded out to expose the basement.

It is significant that these provinces are not stable but boundaries moves and, characteristically, were changed throughout the Cenozoic era (Takeuchi, 1981, 1986, 1999). From the end of Miocene through Pliocene, fold belts were developed on the NEJ side east of ISTL and the Toyama Trough. On the SWJ side, no remarkable deformation occurred in the reverse fault province, except for mountain building of the Japanese Alps due to intense activity of acidic magmas, especially during from 3 to $2 \mathrm{Ma}$ (Harayama, 1992; Yamada and Harayama, 1999). For the
Miocene time, totally different, extensional conditions are postulated on the block movement by normal faults in the basement of sedimentary sequences (block faulting: cf. Takeuchi, 1986) and intense intrusion of granitic rocks, as mentioned in detail in the following section.

\section{Tectonic History}

On the basis of previous studies (e.g. Takeuchi, 1978, 1981; Yamagishi and Kosaka, 1991; Tateishi et al., 1992; Harayama, 1998; Uno and Hoyanagi, 2000; Okamura, 2003), the history of the geological features and structural development of this region is outlined in the following. Figure 5 (middle and bottom) illustrates a model of the structural development along the cross-section from the northern end of the Matsumoto basin to CUZ (Om-Km in Fig. 2; profile line is also shown in Fig. 3), according to Yamagishi and Kosaka (1991), slightly changed based on the interpretation of geohistory on the structural development by Takeuchi (1981, 1999). Figure 7 is a time-space diagram for the geohistorical events that occurred in the junction area among the SWJ and NEJ arcs.

\subsection{Miocene extension regime}

During the Early Miocene period, Fossa Magna and the Toyama Trough accommodated opposite directions of arc rotation known as the $16 \mathrm{Ma}$ bending of the Honshu arc 


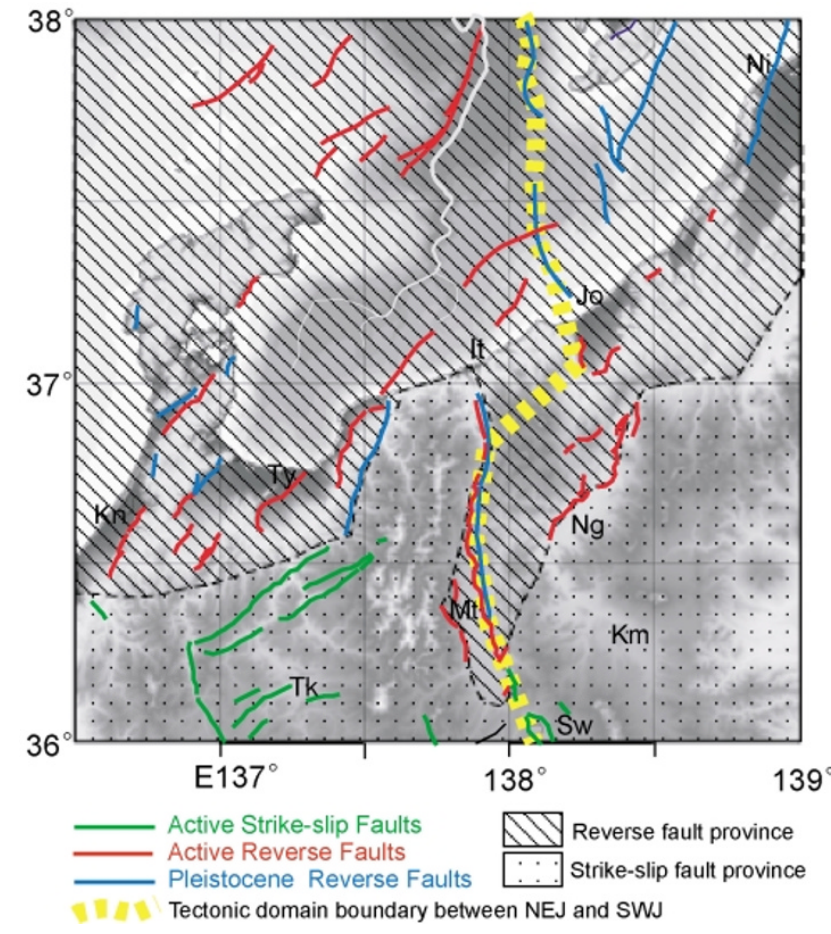

Fig. 6. Active fault provinces in the inner (Japan Sea) side of central Japan. Present-day active strike-slip faults (green colored) are concentrated to the west of ISTL, where Cretaceous and earlier hard rocks are well exposed (dotted). Active thrust faults (red colored) are distributed in the thick sedimentary sequences in the North Fossa Magna and in the Toyama Trough and Toyama Plain (obliquely striped by solid thin lines). The recent reverse fault province also includes Early Pleistocene reverse faults in N-S trends (blue colored), although they are recently inactive. Yellow colored, thick broken line denotes a tectonic boundary identified from the fault distribution pattern between the NEJ and SWJ arcs. Thrusts inverted from normal faults are common east of the yellow boundary while Miocene fault-bounded basins tend to be preserved west of the line. Abbreviations for locality names is the same as in Fig. 2.

demonstrated by paleomagnetic studies (Hirooka et al., 1986; Takeuchi, 1986). As a result, the Honshu arc had evolved into Northeast (NEJ) and Southwest Japan (SWJ) arcs. Each intra-arc rifting occurred in their inner belts, and different trends of faults adjoined along the ISTL and Toyama Trough (Fig. 1). In the North Fossa Magna region, NE-SW trending normal faults had divided the western sedimentary basin (WSB) into two sub-basins (MB and NB in Fig. 3), accompanied by an oblique (N-S) fault parallel to the ISTL, the Otari-Nakayama faults (Fig. 5, middle). One can regard this phenomenon as a reactivation behavior of the northern ISTL.

The North Fossa Magna region is distinguished from the Niigata sedimentary basin to the north with reference to sedimentological facies and modes of folded structures of the Neogene Tertiary system. First, the Miocene system is divided into three major tectonic belts, the western sedimentary basin (NB+MB), the central upheaval zone $(\mathrm{CUZ}+\mathrm{KB})$ and the Kanto mountain area (KM) (Kosaka, 1999). The geologic body CUZ is characterized as a remarkable intrusive zone of Oligo-Miocene granitoids and related geothermal alteration of marine sediments, which is represented by fossil shells of Calyptogena. On the other hand, in the western basin (WSB), no autochthonous vol- canism has been known but differential block tectonics in subsiding movement were recognizable by means of thickness variation of the middle to late Miocene formations, as discussed later.

\subsection{Pliocene and later compression regime}

At the end of the Miocene, a convergent tectonics characterized by fault-controlled folds had commenced along the island-arc margin of the Japan Sea. Such a new diastrophism due to a reversal in the tectonic stress field caused a tectonic inversion, where the style of crustal movement switched from horizontal extension into horizontal compression and differential block movements became remarkable (Takeuchi, 1981). Uplifting and folding with volcanic activity also began in the western basin (WSB) so that the above-mentioned sub-basins evolved into the Nishikubiki uplifted belt (NB) and the Minochi folded belt (MB), respectively. According to the recent results of a field study (Nagamori et al., 2003), rapid uplifting of NB by more than $2 \mathrm{~km}$ relative to $\mathrm{MB}$ occurred within the middle Pleistocene period.

As for the evolution of folded structures, based on paleomagnetic and chronological studies, Niitsuma et al. (2003) reported the mid-Pliocene sinistral rotation in axial directions from a NE-SW trend to a N-S trend, suggesting basement wrenching since $4 \mathrm{Ma}$. The counter-clockwise rotation of fold axes in MB occurred on the southwestern side of the Chikumagawa Tectonic Line (Takeuchi, 1978; facing arrows in Fig. 3) and its northwestern elongation. The rotation suggests a zonal wrenching in the basement of the North Fossa Magna. Such sinuous faults and fold axes are commonly recognized in the northeastern part of the North Fossa Magna and also in the Toyama Trough. However, horizontal rotation cannot be explained with any idea of thin-skinned tectonics (e.g. Yeats et al., 1997) such as uniform shortening of MB on a flat lying detachment fault underlain by the basement.

On the other hand, a tilted uplifting split the Miocene CUZ into the Pliocene and later volcanic zone and the remnant the Komoro basin in KB (Kosaka, 1999; see Fig. 3). A typical tectonic inversion occurred along the western margin of the Nagano basin, which is on the subsided side of the tilted CUZ (Takeuchi, 1981, 1999). Along the boundary between MB and CUZ, westward dipping thrusts and related flexures were recognized as the surface expression of active tectonics as well as surface breaks due to the 1847 Zenkoji Earthquake (M=7.4) (e.g. Ikeda et al., 2002). Uplifting of the Togakushi highlands in MB as well as subsiding of the Nagano basin on CUZ is a typical example of neotectonic inversion of normal faults among Miocene sedimentary sub-basins. A similar inversion was documented in the Toyama Trough (Ishida, 1995). It should be noticed that major anticlines and related thrusts in MB are located along the block boundaries with abrupt changes in layer thickness, and that such phenomena not only designate simple inversion from normal faults to thrusts but also include reorganization from strike-slip faults into reverse ones.

\section{Discussion}

Changes in thickness of strata interpret vertical movements in the sedimentary basin (Fig. 7). After the intense 


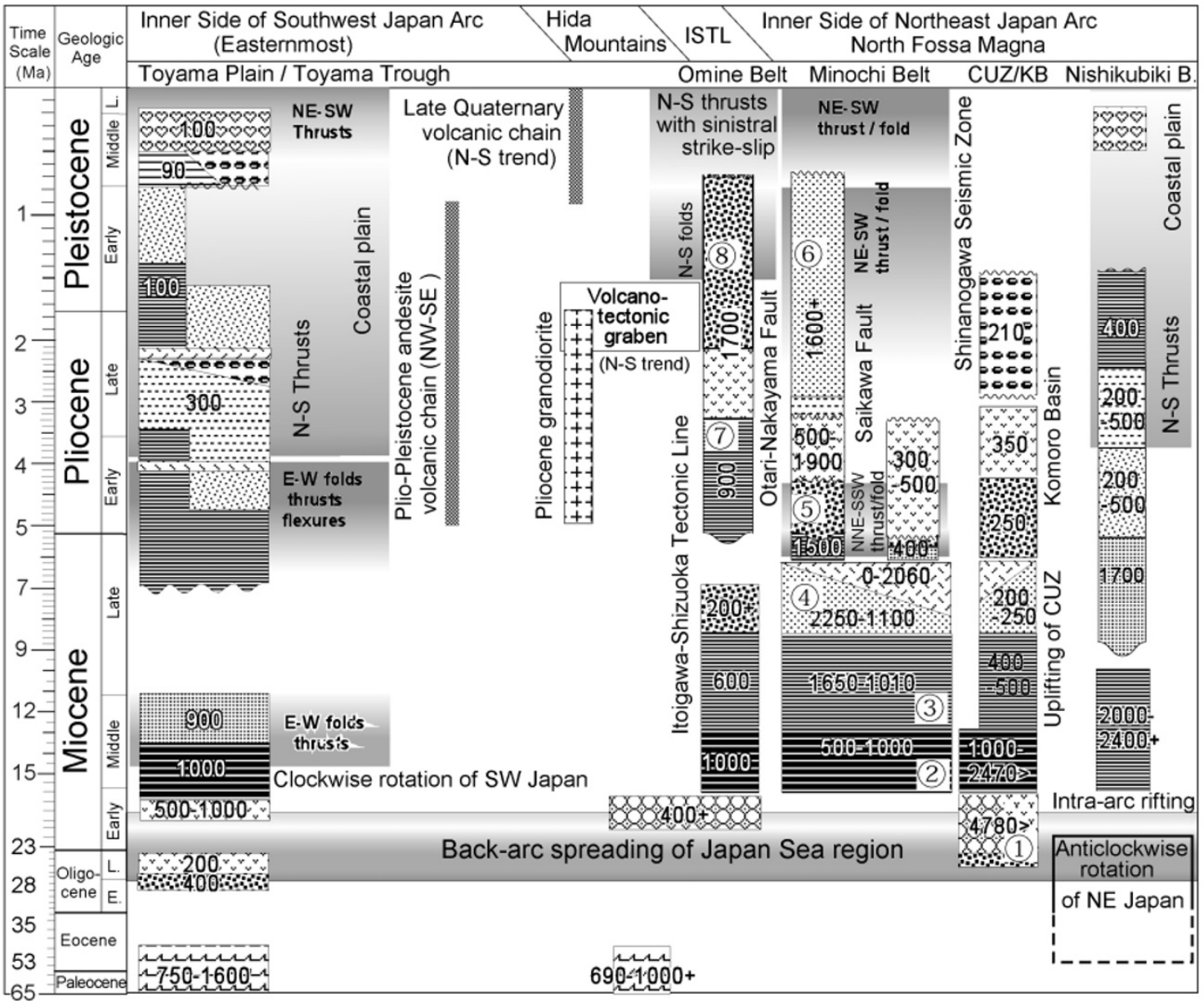

Fig. 7. A time-space diagram for simplified stratigraphy and tectonic events in north-central Japan. After Takeuchi (1999) and GSJ (2003). Numeral labels represent for formation names of the standard stratigraphic units in the North Fossa Magna region: (1): Uchimura Formation, (2): Bessho Fm., (3): Aoki Fm., (4): Ogawa and Omi Fms., (5): Shigarami Fm., (6): Sarumaru Fm., (7): Otari Fm., (8): Omine Fm.

submarine volcanism (some $4000 \mathrm{~m}$ thick products on the CUZ) of the lower Miocene Uchimura formation, thickness of the Bessho formation increased eastward from $1000 \mathrm{~m}$ along the Otari-Nakayama Fault to $2470 \mathrm{~m}$ in the deposition center located on the CUZ, where remarkable uplifting had not yet commenced. Bessho mudstone formation yielded fossil shells of Bivalvia Calyptogena, Adulomya uchimuraensis KURODA, indicating deep-sea hydrothermal activity. Later, in the middle Miocene, the change in thickness of marine sediments (Aoki Formation) ranged from 600-1650 $\mathrm{m}$ in the western basin, to $500-400 \mathrm{~m}$ on the CUZ where dacitic porphyrite had intruded to make a hydrothermal altered zone.

The Late Miocene Ogawa Formation varied its thickness laterally place-by-place among synclines as well as among folded MB and non-folded CUZ areas. It cannot be disregarded that such lateral changes in formation thickness of the same horizon reach a scale of several to ten times. The thickness of Ogawa Formation is $2250 \mathrm{~m}$ in the western wing of Takafu syncline, and 1400-1000 $\mathrm{m}$ in the Komiji syncline. Moreover, the thickness of the folded strata tends to be thick at the sole of the syncline and thinned out along the fold axis of the Saikawa anticline. Contrastingly, 250-200 m thick, non marine sediments were deposited in the wide non deformed domain on the CUZ. These facts indicate a mode of syn-sedimentary tectonics, possibly a differential movement of each block with block faulting (Takeuchi, 1978, 1981).

Such a difference in thickness could not have been produced by deformation after deposition, because the folded structure in MB is mechanically classified into cylindrical folds which developed with layer-parallel sliding, 'bedding slip', without change in layer thickness (Mizuno, 1976). These analytical results suggest that the amounts of subsiding during the Miocene sedimentation differ among basins. Afterwards, each basin was folded with closed anticline between them since the middle Pliocene.

Moreover, within each synclinal domain, almost the same facies of shallow marine sediments had continued to accumulate not only in the late Miocene time before folding but also after the Pliocene period when remarkable folding commenced. Such a continuous accumulation of shallow marine sediments suggests a continuous subsidence through the duration of compressive deformation. Contrastingly, the CUZ had remained stable or relatively uplifted during the middle Miocene and the non-marine environment and erosional condition dominated there through the Late Miocene period.

A simple explanation for the two observation facts mentioned above is difficult by an inversion tectonics of a de- 


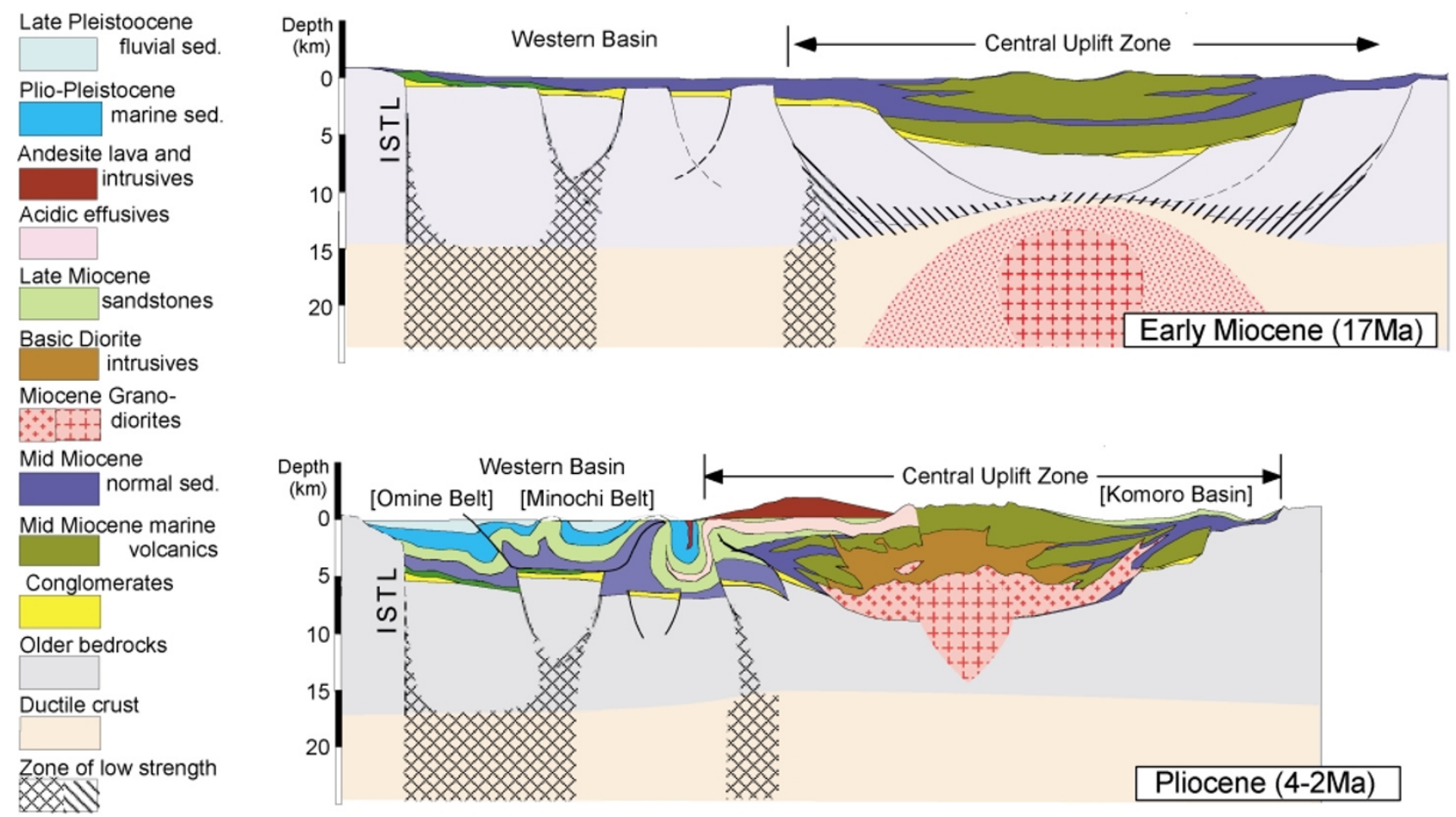

Fig. 8. Cartoon model for the geologic development of the North Fossa Magna and ISTL. [Top: Early Miocene around 17 Ma] Whole area of the North Fossa Magna was emerged by the maximum transgression in the Japan Sea area (Hemipelagic sediments: Blue colored). Submarine volcanism (green colored) with granitic intrusion (red and orange colored) focused on CUZ. Differential block movements due to normal faulting occurred through the Middle Miocene up to the Late Miocene in the basement of the western basin. Horizontal extension and a hot condition are probable in the ductile domain. Trans-tensional strain is postulated to concentrate in the weak zone (hatched). [Bottom] In response to the reversal in the regional stress field which occurred at 6-5 Ma, normal tectonic inversion has been carried out westward within the western basin, where syn-sedimentary folding became remarkable after $4 \mathrm{Ma}$. Trans-contractional strain is postulated to concentrate in the weak zone.

tachment dislocation. Instead, according to the middle to late Miocene history of thickness changes of sedimentary strata, as well as the results of seismic profiling along the Toyama Trough and ISTL, a basement-involved tectonics (Narr and Suppe, 1994) is possible for seismic faulting in the northern Fossa Magna as well as in the western half of central Japan (e.g. Yeats et al., 1997). The latter model puts the dislocation accompanied by two or more dip-slip faults extending downward into the basement of the fold belt (MB). When normal fault movement took place under an extensional regime, it was considered that faults in the upper crust were prolonged into the lower crust and sedimentation carried out more thickly in the hanging wall. When the stress regime had changed into compression, shortening of the sedimentary body was carried out by folding and contraction in the lower crust through accumulated slippage of several faults. The mode of the deformation in the lower crust is mechanically identical to the volumetric change of a certain domain.

Can this model explain the total amount of shortenings or not? In the estimate by Sato et al. (2004), since the spatial variation in thickness of stratigraphic formations is not taken into consideration, then the total amount of shortening strain may have been overestimated. The Suwa basin was formed as a tectonic depression at the southern part of CUZ, where ISTL bends and branches as strike-slip faults running along both sides of the depression (see Figs. 2 and 6). Left-lateral displacement is evident with the remarkable reference to the Median Tectonic Line (MTL), whose dis- location amounts to about $12-14 \mathrm{~km}$ based on the geologic maps (GSJ, 2002b, 2003). Taking the value of displacement for the shortening, total value of contraction strain in the present, $50 \mathrm{~km}$ wide $\mathrm{MB}$, can be estimated at about 19$22 \%$.

If the strain of horizontal shortening was near this value, the additional increase of thickness to the formerly thinned crust by back-arc extension might be small. In the case where an initial thickness of the upper crust was set at 15 $\mathrm{km}$ at the beginning of Pliocene shortening, the crust became thick again by about $6 \mathrm{~km}$, and upheaval is calculated at about $1 \mathrm{~km}$. This estimation seems to fit in with the fact that the elevation of Pleistocene marine sediments is distributed within the Orihashi syncline in Togakushi highlands. By this model, however, it seems still difficult to account for continuous accumulation of shallow-water marine-sediments during the time when folding was carried out. It might be only possible with the help of contemporary sea level rise. Simultaneous uplifting of both arc basement and sea-level is a common geohistorical issue among oil fields in the folded belt along the Japan Sea coast of Honshu Island. In conclusion, the most important matter is a reasonable explanation to account for both the subsiding and folding, mentioned above, together; a 50-100 km wavelength of superposed folding, for example.

\section{Conclusion}

ISTL is not a simple fault but a surface trace of the side wall of the Neogene sedimentary basin, i.e., the North 
Fossa Magna. It terminates the southwestern continuation of inner NEJ arc and controlled the tectonic development of the deformation zone along the eastern margin of the Japan Sea. To examine a tectonic model of the geologic structure of the North Fossa Magna for the Late Miocene, the fact cannot be ignored that differential subsiding among subbasins occurred in the Western basin (MB and NB). Those block movements indicate dip-slip faulting beneath subbasins (synclines), where vertical displacements reached $1000 \mathrm{~m}$ between the Omi and the Komiji synclines, and the Komiji and Takafu synclines, respectively, for example (see Fig. 5).

Other evidence such as the present pattern of seismicity and gravity anomaly, time-space changes in tectonic stresses, and 4 Ma counter-clockwise rotation also support the idea of the basement faulting other than horizontal slippage along the detachment beneath the sedimentary sequences. In response to the neotectonic change at about $6 \mathrm{Ma}$, the intrusion zone of Miocene granites in CUZ had evolved into the volcanic belt and the remnant $\mathrm{KB}$, while the western basin differentiated into subsided MB and uplifted NB.

Based on these facts, this paper regards the geologic structure of the North Fossa Magna as basement-involved (Narr and Suppe, 1994). The deeper form of seismogenic faults beneath ISTL is considered more or less as highangled. According to the linear arrangement of dense distribution of seismicity (Ishikawa, personal comm.), the deeper fault planes are comparatively high-angled parallel to the Omine belt (OB in Figs. 2 and 3) between the northern ISTL active fault system and the surface trace of Otari-Nakayama fault, about $6 \mathrm{~km}$ to the east. Consistently, imaging the results of a regional gravity anomaly, northern ISTL well represents with a sudden change zone of $10-20 \mathrm{~km}$ wide, 20 mgal lower than circumference (Kono, 2003).

Moreover, ISTL cannot be explained as a parallel fault plane formed by the NE-SW trending, intra-arc rifting since the later Early Miocene, but it is possible that ISTL is the more older juncture zone with a N-S trend to form the Kanto syntax of the Honshu arc since the late Eocene (Takeuchi, 1986) through the end of the Oligocene spreading of the Japan Sea region (Tamaki, 1995; see Fig. 7).

Conclusively, a duplex tectonics is probable for the North Fossa Magna region, where the thrust/fold type of deformation in the sedimentary cover is accompanied by the block movement with both reverse and strike-slip senses of faulting in the basement. Most seismic events occur not in the Neogene sedimentary layers but in the bedrocks of the North Fossa Magna (Ishikawa, personal comm.).

The northwest dipping thrust faulting in the Shinanogawa zone is sided by the $10 \mathrm{~km}$ wide, transpressional zone of thrusting along the northern ISTL. According to the middle to late Miocene history of thickness changes of sedimentary strata as well as the results of seismic profiling along the Toyama Trough and ISTL, a basement-involved tectonics, compatible with a 'distributed shear model' in the lower crust for the driving mechanism of seismogenic faulting (Iio and Kobayashi, 2002), is preferable for seismogenic faulting in the northern Fossa Magna. In order to integrate the above-mentioned concepts and observations, Figure 8 illus- trates a possible model for the geologic structure and its development of the North Fossa Magna as a sequence of basement-involved tectonics. A shallower detachment beneath the sedimentary cover, if any, would cause no strong earthquakes. More detailed data on the deeper geologic structure related to the seismogenic faults west of CUZ is necessary to represent the attitude of block boundaries for the purpose of accurately evaluating future strong earthquakes along the northern ISTL.

Acknowledgments. This paper concerns a part of the Program "Comprehensive joint research on the model of slip process of earthquake source fault and plastic flow below the seismogenic region" which is funded by Japanese Ministry of Education, Culture, Sports, Science and Technology. I am grateful to Prof. Dr. Yoshihisa Iio, the chief scientist of the program, for critical discussion on attitude of seismogenic faults in the North Fossa Magna region. I also extend my thanks to Prof. Dr. Hiroaki Tsukahara and Dr. Keiji Takemura for their critical reading and helpful suggestions to improve the manuscript. Finally, I thank Dr. Yuzo Ishikawa at the Japan Meteorological Agency for useful discussions about the seismicity along ISTL.

\section{References}

Geological Survey of Japan, 1:50000 Geological Map "Sakaki”, Geological Survey of Japan, 1980.

Geological Survey of Japan, 1:50000 Geological Map "Shinano Ikeda", Geological Survey of Japan, 1983.

Geological Survey of Japan, AIST, Geological Map East of Noto Peninsula, Marine Geology Map Series no. 59 (CD), Geological Survey of Japan, AIST, Japan, 2002a.

Geological Survey of Japan, AIST, Geological Map of Japan 1:200,000 (Images), Digital Geoscience Map G-3 (CD), Geological Survey of Japan, AIST, Japan, 2002b.

Geological Survey of Japan, AIST, Geological Map of Japan 1:1,000,000, 3rd ed, 2nd CD-ROM Version, Digital Geoscience Map G-1 (CD), Geological Survey of Japan, AIST, Japan, 2003.

Harayama, S., Youngest exposed granitoid pluton on Earth: Cooling and rapid uplift of the Pliocene-Quaternary Takidani Granitoid in the Japan Alps, central Japan, Geology, 20, 657-660, 1992.

Harayama, S., Quaternary Takidani Grannodiorite and Hotaka Andesite in the northern Alps, central Japan, Field Guidebook, 105th Annual Meeting, Geol. Soc. Japan, 129-142, 1998 (in Japanese).

Hirooka, K., H. Sakai, T. Takahashi, H. Kinoto, and A. Takeuchi, Tertiary tectonic movement of central Japan inferred from paleomagnetic studies, Jour. Geomag. Geoelectr., 38, 311-323, 1986.

Iio, Y. and Y. Kobayashi, A physical understanding of large intraplate earthquakes, Earth Planets Space, 54, 1001-1004, 2002.

Ikeda, Y., T. Imaizumi, M. Togo, K. Hirakawa, T. Miyauchi, and H. Sato, Atlas of Quaternary Thrust Faults in Japan, University of Tokyo Press, 254 pp, 2002.

Ishida, H., Characteristics of the basement structure and formation of oil folding: examples of Toyama Bay through Off-Niigata-Kubiki, Annual Rept. TRC's Activities for the Year 1995, 17-24 Japan Oil, Gas, Metal National Corporation (JOGMEC), 1995.

Koike, K. and H. Machida (ed.), Atlas of Quaternary Marine Terraces in Japanese Islands, 105 pp., University of Tokyo Press, 2001.

Kono, Y., Gravity anomalies well correlated with geological structures in central Japan-Conrad/Moho/Slab Residual Bouguer Anomalies (CMS/RBA) —, Earth Monthly, 25, 953-960, 2003 (in Japanese).

Kosaka, T., Geology of the Omine Belt and its geological significances in a tectonic history of the Fossa Magna region, Central Japan, Jour. Fac. Sci., Shinshu Univ., 26, 2, 74-140, 1991.

Kosaka, T., Geology and tectonics of the Omine Belt, west margin of the northern Fossa Magna region, Chikyu Monthly, 21, 9, 589-595, 1999 (in Japanese).

Mizuno, M., Geology of the northern Higashi-Chikuma District, Nagano Prefecture: On the consentric folding of Komiji syncline and Noma anticline, Memoir of Geol. Soc. Japan, no. 13, 187-201, 1976 (in Japanese).

Nagamori, H., R. Furukawa, and K. Hayatsu, Geology of the Togakushi district, 1:50,000 Geologic Map 'Togakushi', Geol. Surv. Japan, AIST, 2003. 
Nakamura, K. and T. Matsuda, Geologic province and seismic activity in the northern Fossa Magna and surrounding region, central Japan, Memoir of Geol. Soc. Japan, no. 2, 63-69, 1968 (in Japanese).

Nakamura, K. and S. Uyeda, Stress gradient in arc-back arc region and plate subduction, Jour. Geophys. Res., 85, 6419-6428, 1980.

Nakata, T. and M. Imaizumi (ed.), Digital Active Fault Map of Japan, DVDs and explanation (68 pp.), University of Tokyo Press, 2000.

Narr, W. and J. Suppe, Kinematics of basement-involved compressive structures, Amer. Jour. Sci., 294, 802-860, 1994.

Niitsuma, S., N. Niitsuma, and K. Saito, Evolution of the Komiji Syncline in the North Fossa Magna, central Japan: Paleomagnetic and K-Ar age insights, The Island Arc, 12, 310-323, 2003.

Okamura, Y., Fault-related faults and an imbricate thrust system on the northwestern margin of the northern Fossa Magna region, central Japan, The Island Arc, 12, 62-73, 2003.

Sato, H., T. Iwasaki, Y. Ikeda, T. Takeda, N. Matsuta, T. Imai, E. Kurashimo, N. Hirata, S. Sakai, D. Elouai, T. Kawanaka, S. Kawasaki, S. Abe, T. Kozawa, T. Ikawa, Y. Arai, and N. Kato, Seismological and geological characterization of the crust in the southern part of northern Fossa Magna, central Japan, Earth Planets Space, 56, this issue, 12551261, 2004.

Sugimura, A. and S. Uyeda, Island Arcs: Japan and Its Environs, Elsevier, 247 pp, 1973.

Takeuchi, A., The Pliocene stress field and tectonism in the Shin-Etsu region, central Japan, Jour. Geosciences, Osaka City Univ., 21, 37-52, 1978.

Takeuchi, A., Temporal changes of regional stress field and tectonics of sedimentary basin, Jour. Geol. Soc. Japan, 87, 737-751, 1981.

Takeuchi, A., Oligocene/Miocene rotational block-movement and paleostress field of Japan, Jour. Geomag. Geoelectr., 38, 495-511, 1986.

Takeuchi, A., Pliocene and later vicissitude of stress field and tectonics in the Hoku-Shin-Etsu district, central Japan, Earth Monthly, 21, 583-588,
1999 (in Japanese).

Takeuchi, A. and Shipboard Scientific Party of R/V Yokosuka, Japan Sea Cruise, Bottom response to a tsumami earthquake: Submersible observations in the epicenter area of the 1993 earthquake off southwestern Hokkaido, Sea of Japan, Jour. Geophys. Res., 103(B10), 24109-24125, 1998.

Tamaki, K., Opening tectonics of the Japan Sea, in Back arc Basins: Tectonics and Magmatism, edited by B. Taylor, pp. 407-420, Plenum Press, New York, 1995.

Tateishi, M., S. Kakizaki, O. Takano, M. Higashi, K. Sugiyama, and M. Endo, Sedimentary facies and tectonic movement-Turbidite basin of the Kubiki-Otari district in the northern Fossa Magna-, in Neogene in the Eastern Margin of the Paleo Sea of Japan-Stratigraphy, Paleogeography and Paleoenvironment, Memoir Geol. Soc. Japan, 37, 249-259, 1992.

Uno, T. and T. Hoyanagi, Provenance and dispersal systems of the Neogene sandstone in the northern Fossa Magna, Nagano Prefecture, central Japan, in Compositions of Siliciclastic Rocks in relation to Provenance, Tectonics and Sedimentary Environments, Memoirs Geol. Soc. Japan, 57, 231-240, 2000.

Yamada, R. and S. Harayama, Fission track and K-Ar dating on some granitic rocks of the Hida Mountain Range, central Japan, Geochem. Jour., 33, 59-66, 1999.

Yamagishi, I. and T. Kosaka, Pliocene-Early Pleistocene Tectonic Movement in the northern Fossa Magna, central Japan, in Uplifting of the Fossa Magna, Monograph 38, pp. 129-140, Assoc. Geol. Collab. Japan, 1991.

Yeats, R., K. Sieh, and C. R. Allen, The Geology of Earthquakes, 568 pp, Oxford Univ. Press, 1997.

A. Takeuchi (e-mail: takeuchi@sci.toyama-u.ac.jp) 